\title{
Karakteristik dan Potongan Komersial Karkas Domba Muda Umur Lima Bulan yang diberi Ransum Komplit Mengandung Minyak Biji Bunga Matahari
}

\author{
Characteristic and Commersial Cutting of Five Months Young Sheep Carcass that Fed by Complete Ration Contained \\ Sunflower Seed Oil \\ L Khotijah'1 ${ }^{1}$ T Suryati ${ }^{2}$, M Fandi ${ }^{1}$
}

Corresponding email:

Lilis.khotijah@gmail.com

1)Departemen Ilmu Nutrisi dan Teknologi Pakan, Fakultas

Peternakan, Institut Pertanian Bogor (Bogor Agricultural

University/IPB University)

2)Departemen Ilmu Produksi dan Teknologi Peternakan, Fakultas Peternakan, Institut Pertanian Bogor (Bogor Agricultural University/IPB University)

\section{ABSTRACT}

The aim of the study was to evaluate the effect of graded levels of sunflower seed oil (SSO) supplementation on lamb five-month-old carcass characteristics and commercial cuts. Used 18 local male lambs, weaned, aged about 2 months, weight $(10.21 \pm 2.29 \mathrm{~kg})$. Experimental design used group random design. Each group of sheep get a complete ration with a different level of sunflower seed oil (SSO), namely (P0) = 0\% SSO (control); (P1) = $4 \%$ SSO; (P2) $=6 \%$ SSO. After animal five old age or 90 days feeding, randomly selected tree animals from each group were slaughtered The measured parameters include, weight slaughter, carcasses composition (meats, bones, fats), and commercial cuts of carcasses (leg, loin, shoulder, breast, neck, shank, flank, rack). The observation showed that the parameters are not affected by the treatment. It can be concluded that the addition of $6 \%$ sunflower oil in a complete ration keeping the characteristics and commercial cut of local lamb.

Key words: slaughter weight, carcass composition, lamb, sunflower seed oil

\section{ABSTRAK}

Penelitian bertujuan untuk mengevaluasi pengaruh suplementasi minyak bunga matahari (MBBM) dalam ransum komplit terhadap karakteristik dan potongan komersial karkas domba berumur lima bulan. Digunakan 18 ekor ekor anak domba lokal jantan lepas sapih berumur sekitar 2 bulan, bobot badan $(10,21 \pm 2,29 \mathrm{~kg})$. Penelitian menggunakan Rancangan Acak Kelompok, setiap kelompok domba mendapatkan ransum komplit dengan kadar minyak biji bunga matahari (MBBM) berbeda, yaitu (P0)= $\%$ MBBM (kontrol); (P1)= 4\% MBBM; (P2)=6\% MBBM. Pemotongan dilakukan setelah domba berumur lima bulan atau 90 hari pemberian pakan perlakuan. Secara acak masing-masing diambil 3 ekor dari setiap perlakuan. Peubah yang diamati meliputi bobot potong, komposisi karkas (daging, tulang, lemak) dan potongan karkas komersial (leg, loin, shoulder, breast, neck, shank, flank, rack). Hasil pengamatan menunjukkan bahwa perlakuan tidak memberikan pengaruh yang berbeda nyata terhadap smua peubah yang diukur Dapat disimpulkan bahwa penambahan minyak biji bunga matahari sampai $6 \%$ dalam ransum komplit menghasilkan bobot potong, karakteristik dan potongan karkas komersial yang sesuai standar domba lokal muda.

Kata kunci: domba muda, komposisi karkas, minyak bunga matahari, potongan komersial 


\section{PENDAHULUAN}

Permintaan daging domba muda sebagai sumber protein hewani berkualitas, aman dan menyehatkan semakin meningkat, sejalan dengan meningkatnya kesadaran akan konsumsi produk pangan sehat. Ternak yang dipotong pada umur yang masih muda menghasilkan produk daging dengan tekstur dan keempukan yang baik, namun bobot potongnya lebih rendah dari ternak dewasa (Rousset-Akrim et al. 1997). Saat ini permintaan masyarakat terhadap daging domba muda cenderung meningkat, terbukti dengan makin berkembangnya kuliner yang menyajikan olahan makanan daging domba muda dibawah lima bulan. Permintaan yang tinggi terhadap daging domba muda tersebut menyebabkan peternak harus mampu menyediakan domba muda siap potong dalam waktu yang lebih cepat.

Sistem pemeliharaan domba yang masih konvensional masih belum mampu mencapai bobot potong yang diinginkan. Kajian Suharto dan Layla (2005), domba yang dipelihara secara konvensional hingga umur 7 bulan hanya mencapai bobot potong 9-15 kg. Purbowati et al. (2007) domba yang dipelihara secara feedlot dari umur 5 bulan hingga umur 7 bulan dapat mencapai bobot potong lebih tinggi, yaitu 15-25 kg. Hal ini menyebabkan perlunya suatu cara untuk meningkatkan bobot potong dengan percepatan pertumbuhan domba, sehingga siap potong pada umur muda. Salah satu hal penting yang dapat mendukung tercapainya perumbuhan yang cepat adalah faktor pakan.

Pemberian pakan yang harus mendukung kecepatan pertumbuhan domba muda terkendala dengan kapasitas konsumsi domba muda yang terbatas, sehingga perlu diberikan pakan dengan densitas zat makanan tinggi.. Salah satu komponen zat makanan yang berperan penting dalam meningkatkan laju pertumbuhan domba adalah energi. Pemberian ransum berenergi tinggi pada domba jantan muda dapat menghasilkan laju pertumbuhan dan bobot potong yang tinggi (Ensminger 2002).

Perbaikan kualitas melalui suplementasi sumber energi dalam ransum, karena untuk menaikan performa produksi dan kualitas fisik daging domba maka diperlukan ransum dengan energi yang tinggi (Gatenby et al. 1995). Domba jantan muda yang diberi ransum berenergi tinggi akan menghasilkan bobot potong lebih tinggi dan sifat fisik yang lebih baik (Ensminger 2002). Informasi penggunaan minyak sebagai sumber energi dalam ransum diantaranya, minyak kelapa sawit atau Crude Palm Oil, dan minyak kelapa sudah cukup banyak, namun masih terbatas informasi penggunaan minyak nabati yang kaya asam lemak esensial seperti minyak biji bunga matahari, sehingga perlu dilakukan kajian pemberian minyak biji bunga matahari yang dipadukan dengan bungkilnya dalam ransum komplit. Kandungan energi dalam minyak ini sangat bermanfaat bagi ternak karena dapat memperbaiki presentase karkas pada domba lokal dan kualitas fisik, sementara kandungan asam lemak tak jenuh pada MBBM dapat meningkatkan kandungan asam lemak tidak jenuh pada daging domba (Elizabeth dan Susana 2013). Penambahan minyak biji bunga matahari (MBBM) selain sebagai sumber energi juga sebagai sumber asam lemak esensial, terutama asam lemak linoleat.

Berdasarkan uraian di atas penelitian ini bertujuan untuk mempelajari pengaruh penambahan minyak bunga matahari dengan level yang berbeda dalam ransum komplit terhadap bobot potong, komposisi dan potongan karkas komersial domba lokal jantan muda umur 5 bulan.

\section{METODE}

\section{Ternak dan Ransum}

Delapan belas ekor domba jantan lokal lepas sapih, berumur sekitar 2 bulan dengan bobot badan 10,21 \pm $2,29 \mathrm{~kg}$. Ternak dipelihara sampai mencapai umur 5 bulan atau pemberian pakan perlakuan 90 hari, diambil 3 ekor dari setiap perlakuan untuk dipotong mengikuti prosedur pemotongan karkas dan potongan komersial karkas berdasarkan Romans dan Ziegler (1977) dan SNI (2008).

Tabel 1 Komposisi dan kadar zat makanan ransum penelitian berdasarkan bahan kering

\begin{tabular}{|c|c|c|c|}
\hline \multirow{2}{*}{ Bahan pakan } & \multicolumn{3}{|c|}{ Ransum Perlakuan } \\
\hline & $\mathrm{PO}$ & P1 & $\mathrm{P} 2$ \\
\hline & \multicolumn{3}{|c|}{$\ldots \ldots$ BK - . . . } \\
\hline Onggok & 32,1 & 28,1 & 26,1 \\
\hline Bungkil kelapa & 57,0 & 57,0 & 57,0 \\
\hline Bungkil biji bunga matahari & 10,0 & 10,0 & 10,0 \\
\hline Minyak bunga matahari & - & 4,0 & 6,0 \\
\hline $\mathrm{CaCO}_{3}$ & 0,2 & 0,2 & 0,2 \\
\hline Garam & 0,2 & 0,2 & 0.2 \\
\hline Premix & 0,5 & 0,5 & 0,5 \\
\hline Jumlah & 100 & 100 & 100 \\
\hline \multicolumn{4}{|l|}{ Zat Makanan } \\
\hline Bahan kering & 89,60 & 90,00 & 90,10 \\
\hline Protein kasar & 15,10 & 15,00 & 15,00 \\
\hline Lemak kasar & 5,80 & 8,80 & 10,30 \\
\hline Serat kasar & 22,80 & 22,50 & 22,30 \\
\hline Beta-N & 54,90 & 52,27 & 50,99 \\
\hline TDN & 75,20 & 79,31 & 81,36 \\
\hline Kalsium (Ca) & 0,90 & 0,87 & 0,86 \\
\hline Phosfor (P) & 0,50 & 0,56 & 0,55 \\
\hline
\end{tabular}

(P0) = 0\% MBBM (kontrol); (P1) = 4\% MBBM; (P2) = 6\% MBBM 
Ransum yang diberikan, berupa ransum komplit dengan kadar Minyak bunga matahari (MBBM) berbeda, yaitu P0 (0\%); P1 (4\%) dan P3 (6\%). Ransum disusun berdasarkan Nutrient Requirement Council (2006) (Tabel 1).

\section{Pengukuran Peubah}

Peubah yang diukur meliputi bobot potong, karakteristik karkas dan potongan komersial karkas domba berumur 5 bulan. Domba penelitian dipotong untuk mendapatkan karkas dan potongan komersial karkas berdasarkan Romans dan Ziegler (1977) dan SNI (2008). Domba dipotong setelah terlebih dahulu dipuasakan selama 16 jam untuk mengurangi jumlah digesta dalam saluran pencernaan, selanjutnya ditimbang untuk mendapatkan bobot potongnya. Pemotongan domba dilakukan pada persendian tulang atlas, memotong vena jugularis, oesophagus dan trakea. Darah yang keluar ditampung hingga tuntas kemudian dilakukan pemotongan kepala dan keempat kaki bagian bawah. Bagian kepala dipotong pada persendian occipito atlatis, bagian kaki depan dipotong pada persendian carpal-metacarpal dan bagian kaki belakang dipotong pada persendian tarsusmetatarsus kemudian domba digantung pada tendon achilesnya. Setelah itu dilakukan pengulitan dan eviserasi, maka diperoleh karkas segar dan kemudian ditimbang.

Karkas dibelah menjadi dua bagian yang sama pada tulang belakang yaitu bagian kiri dan bagian kanan. Bagian kanan ditimbang untuk digunakan sebagai bobot setengah karkas segar. Karkas kemudian disimpan dalam alat pendingin $\left(4^{\circ} \mathrm{C}\right)$ untuk diuraikan keesokan harinya. Keesokan harinya, karkas bagian kanan diuraikan menjadi delapan potongan komersial yaitu paha (leg), pinggang (loin), rack, bahu (shoulder), dada (breast), leher (neck), lengan (shank), dan lipat paha (flank) (Romans dan Ziegler 1977). Setelah didapatkan potongan komersial, masing-masing potongan tersebut ditimbang kemudian dipisahkan antara daging, tulang, dan lemak.

Bobot dan persentase karkas. Bobot karkas adalah bobot tubuh ternak setelah dipotong dikurangi darah, kepala, keempat kaki, kulit, isi rongga perut, isi rongga dada dan ekor (g). Persentase karkas diperoleh dengan menggunakan rumus:

karkas $(\%)=\frac{A}{B} \times 100 \%$;

A : Bobot karkas (kg); B : Bobot potong (kg)

\section{Bobot dan persentase daging, lemak, dan tulang karkas.}

Bobot dan persentase daging/ lemak/ tulang karkas adalah hasil penimbangan bagian dari pemisahan daging, lemak serta tulang yang sudah dipisahkan kemudian dibandingkan dengan karkas utuh untuk mengetahui persentasenya. Persentase daging, lemak dan tulang karkas diperoleh dengan rumus:

komponen karkas $(\%)=\frac{W}{A} \times 100 \%$

W : Bobot komponen karkas (lemak/daging/tulang) (kg)

A : Bobot karkas (kg)

Bobot dan persentase potongan komersial karkas. Potongan komersial yang ditimbang bobot dan presentase nya meliputi paha (leg), pinggang (loin), bahu (shoulder), dada (breast), leher (neck), lengan (shank), dan lipat paha (flank) dan rack (g). Persentase potongan komersial karkas diperoleh dengan rumus:

Potongan komersil (\%) $=\frac{C}{\mathrm{~A}} \times 100 \%$

$\mathrm{A}=$ Bobot karkas $(\mathrm{kg}) ; \mathrm{C}=$ Bobot potongan komersil $(\mathrm{kg})$

\section{Rancangan Percobaan dan Analisis Data}

Rancangan percobaan yang digunakan adalah Rancangan Acak Kelompok dengan 3 perlakuan dan 6 ulangan. Data yang diperoleh dianalisis dengan sidik ragam (analysis of variance, ANOVA) dan apabila terdapat perbedaan nyata dilanjutkan dengan uji Duncan (Steel dan Torrie 1993).

\section{HASIL DAN PEMBAHASAN}

\section{Bobot Potong dan Komposisi Karkas}

Bobot potong dan komposisi karkas domba jantan muda dengan ransum komplit mengandung level MBBM berbeda disajikan pada Tabel 2. Hasil analisis statistik menunjukkan bahwa pemberian ransum komplit dengan kandungan minyak biji bunga matahari (MBBM) berbeda, tidak berpengaruh nyata terhadap bobot potong domba muda umur 5 bulan. Bobot potong yang dihasilkan (Tabel 2) lebih tinggi dibandingkan bobot potong domba muda hasil penelitian Suharto dan Layla (2005) yang dipelihara secara konvensional sampai umur 7 bulan, dengan pencapaian bobot 9-15 kg. Hasil penelitian ini sejalan dengan Purbowati et al. (2007) yang melaporkan bahwa bobot potong domba jantan muda berkisar 15-20 kg dengan PBB 154,3 g ekor-lhari-1 $^{-1}$

Secara statistik kadar minyak bunga matahari berbeda dalam ransum komplit tidak memberikan pengaruh yang nyata $(\mathrm{P}>0.05$ ) terhadap bobot potong dan komposisi karkas domba muda yang dihasilkan. Persentase karkas domba berada pada kisaran 43\% 45\%. Nilai ini lebih tinggi dari yang dihasilkan Wiryawan et al. (2009) bahwa domba ekor tipis yang diberi legume dan dipotong pada umur muda menghasilkan karkas sebesar 38,8\% . Bobot dan persentase karkas dari penelitian ini juga lebih tinggi dibandingkan hasil penelitian Alwi (2009), bahwa domba ekor tipis jantan 
Tabel 2 Bobot potong dan komposisi karkas domba lokal jantan umur 5 bulan

\begin{tabular}{|c|c|c|c|}
\hline \multirow{2}{*}{ Bagian Karkas } & \multicolumn{3}{|c|}{ Ransum Perlakuan } \\
\hline & PO & P1 & P2 \\
\hline Bobot Potong (kg) & $19,17 \pm 3,20$ & $18,18 \pm 4,55$ & $19,68 \pm 4,53$ \\
\hline Karkas (kg) & $8,93 \pm 1,98$ & $8,23 \pm 2,30$ & $9,28 \pm 2,41$ \\
\hline Karkas (\%) & $45,03 \pm 3,91$ & $44,26 \pm 0,83$ & $43,69 \pm 2,37$ \\
\hline Karkas kiri (kg) & $4,40 \pm 0,22$ & $4,14 \pm 1,28$ & $4,64 \pm 0,90$ \\
\hline Daging $1 / 2$ karkas (kg) & $2,62 \pm 0,87$ & $2,40 \pm 0,63$ & $2,74 \pm 0,72$ \\
\hline Daging $1 / 2$ karkas (\%) & $59,82 \pm 2,44$ & $58,76 \pm 2,05$ & $58,69 \pm 3,51$ \\
\hline Tulang $1 / 2$ karkas (kg) & $1,06 \pm 66,3$ & $1,02 \pm 0,28$ & $1,14 \pm 0,08$ \\
\hline Tulang $1 / 2$ karkas (\%) & $24,21 \pm 0,28$ & $24,91 \pm 0,47$ & $24,57 \pm 2,76$ \\
\hline Lemak $1 / 2$ karkas (kg) & $0,70 \pm 0,14$ & $0,65 \pm 0,26$ & $0,67 \pm 0,07$ \\
\hline Lemak $1 / 2$ karkas (\%) & $15,40 \pm 2,08$ & $15,02 \pm 0,77$ & $14,86 \pm 0,83$ \\
\hline
\end{tabular}

umur satu tahun yang mengonsumsi pakan dengan tambahan kulit singkong memiliki rataan bobot karkas sebesar 8,07 kg dengan rataan persentase karkas sebesar 40,81\%, lebih tinggi dari penelitian Sumira (2010), domba lokal jantan umur enam bulan yang diberikan pakan rumput, legum pohon, dan konsentrat memiliki bobot karkas sebesar 5,94 kg dengan persentase karkas sebesar 33,96\%. Hal ini memberikan gambaran bahwa perbaikan pemberian pakan pada domba yang akan dipotong pada umur muda, berupa tambahan minyak nabati asal bungkil biji bunga matahari dapat memperbaiki bobot potong dan persentase karkas yang dihasilkan.

Hasil lain menunjukkan pula bahwa semakin tinggi penambahan minyak dalam ransum maka persentase karkas yang dihasilkan akan semakin kecil, hal ini bertentangan dengan pernyataan Gatenby (1995) bahwa semakin besar energi ransum yang menunjang untuk pertumbuhan akan menghasilkan bobot potong yang lebih tinggi dan persentase karkas yang lebih besar pula.

Bobot daging yang dihasilkan berkisar 2,40 kg - 2,74 $\mathrm{kg}$, atau sekitar 58\% - 59\% dari karkas. Menurut penelitian Herman (1993) daging yang dihasilkan oleh domba berkisar $56.03 \%$ hingga $65.03 \%$. Hasil diatas menunjukkan korelasi yang positif antara berat karkas dan bobot daging karena semakin tinggi berat karkas maka bobot daging yang dihasilkan akan meningkat, Hal ini sesuai penelitian Rasmani (2010) yang menunjukkan bahwa semakin tinggi bobot karkasnya maka semakin banyak pula daging yang dihasilkan. Penelitian Sumira (2010) menunjukkan bahwa domba lokal jantan umur enam bulan memiliki rataan bobot tulang sebesar 862,98 gram dengan persentase $29,21 \%$. Persentase bobot tulang pada berbagai perlakuan relatif sama yaitu berada diangka $24 \%$, nilai ini lebih rendah dari hasil penelitian Sumiar (2010), bahwa bahwa domba lokal jantan umur enam bulan menghasilkan rataan bobot tulang sebesar 862,98 gram dengan persentase $29,21 \%$.
Persentase lemak yang dihasilkan berkisar 14,86\% $15,40 \%$. Penambahan MBBM ke dalam ransum menurunkan persentase lemak dalam karkas. Hal ini sejalan dengan penelitian Purbowati (2006) dimana domba muda yang memiliki bobot potong $15 \mathrm{~kg}$ memiliki kadar lemak yang lebih tinggi dibanding dengan domba muda yang memiliki bobot potong $20 \mathrm{~kg}$. Hal ini dapat juga terjadi karena domba sedang dalam fase pertumbuhan, sehingga konsumsi energi dialokasikan untuk pertumbuhan tidak pada deposit lemak.

Secara keseluruhan karakteristik karkas yang dihasilkan tidak dipengaruhi oleh kadar minyak bunga matahari dalam ransum komplit, Hal ini sejalan dengan hasil penelitian Marinova et al. (2001) dengan memberikan ransum mengandung minyak bunga matahari tidak mempengaruhi laju pertumbuhan, pertambahan bobot badan harian, persentase karkas , komposisi karkas anak kambing; hasil ini juga sejalan dengan Mir et al., (2003),bahwa penambahan minyak bunga mata hari sampai $6 \%$ dalam ransum sapi, tidak mempengaruhi karakteristik karkas yang dihasilkan. Gonzáleza et al. (2014), juga menyatakan bahwa pemberian konsentrat komersial mengandung 4,5\% minyak bunga matahari tidak mempengaruhi performa dan karakteristik karkas anak sapi.

\section{Potongan Komersial Karkas}

Bobot dan potongan komersial karkas yang dihasilkan domba umur 5 bulan yang mendapat ransum komplit mengandung kadar minyak bunga matahari berbeda disajikan pada Tabel 3.

Tabel 2 Rataan bobot dan persentase potongan komersial karkas domba lokal jantan umur 5 bulan

\begin{tabular}{lrrr}
\hline Bagian & \multicolumn{3}{c}{ Perlakuan } \\
\cline { 2 - 4 } Karkas & \multicolumn{1}{c}{$\mathrm{P} 0$} & \multicolumn{1}{c}{$\mathrm{P} 1$} & $\mathrm{P} 2$ \\
\hline Loin $(g)$ & $409,67 \pm 107,75$ & $430,53 \pm 184,03$ & $471,37 \pm 130,02$ \\
Loin (\%) & $9,23 \pm 0,59$ & $10,14 \pm 1,37$ & $10,18 \pm 1,03$ \\
Rack $(g)$ & $426,47 \pm 94,47$ & $380,20 \pm 166,98$ & $389,33 \pm 73,66$ \\
Rack (\%) & $9,68 \pm 0,68$ & $8,94 \pm 1,28$ & $8,53 \pm 1,16$ \\
Flank (g) & $111,47 \pm 42,67$ & $114,23 \pm 24,69$ & $115,50 \pm 31,53$ \\
Flank (\%) & $2,47 \pm 0,56$ & $2,80 \pm 0,33$ & $2,69 \pm 1,40$ \\
Breast (g) & $466,23 \pm 90,70$ & $440,37 \pm 114,63$ & $501,43 \pm 156,10$ \\
Breast (\%) & $10,64 \pm 0,78$ & $10,70 \pm 0,39$ & $10,69 \pm 0,79$ \\
Shoulder (g) & $1248,07 \pm 358,17$ & $1088,07 \pm 224,16$ & $1249,97 \pm 373,21$ \\
Shoulder (\%) & $27,99 \pm 2,76$ & $26,70 \pm 2,13$ & $26,71 \pm 1,79$ \\
Leg $(g)$ & $1383,57 \pm 263,36$ & $1214,53 \pm 124,24$ & $1528,27 \pm 383,05$ \\
Leg $(\%)$ & $31,57 \pm 1,98$ & $30,36 \pm 5,21$ & $32,95 \pm 0,37$ \\
Shank (g) & $354,63 \pm 26,54$ & $278,50 \pm 43,43$ & $381,40 \pm 108,77$ \\
Shank (\%) & $8,32 \pm 1,97$ & $6,89 \pm 0,86$ & $8,17 \pm 0,59$ \\
\hline P0=0\% MBBM (kontrol); $\mathrm{P} 1=4 \% \mathrm{MBBM} ; \mathrm{P} 2=6 \% \mathrm{MBBM}$ &
\end{tabular}


Secara statistik pemberian ransum komplit dengan kadar minyak bunga matahari sampai $6 \%$ tidak menghasilkan potongan komersial karkas yang berbeda nyata dengan kontrol. Hasil ini sejalan dengan komposisi karkas yang juga tidak berbeda nyata. Persentase loin berada pada persentase yang hampir sama di setiap perlakuan yaitu 9,23\%-10,18\%. Menurut Lambuth (1970) loin merupakan bagian karkas yang tumbuhnya paling lambat sehingga persentase loin relatif sama pada domba meskipun dengan kecepatan tumbuh yang berbeda. Menurut AUS-MEAT (2005) persentase loin pada karkas domba yaitu $12.1 \%$. Pada penelitian nilai loin masih di bawah standar Australian meat standard AUS-MEAT (2005), namun jika dibandingkan dengan hasil penelitian Rahayu et al. (2011), yang memberikan ransum mengandung indigofera dan limbah toge pada domba muda di bawah satu tahun, berat loin yang dihasil penelitian ini masih lebih besar. Masih lebih rendahnya dibanding standard AUS-MEAT (2005), diduga berkaitan dengan umur domba yang belum mencapai dewasa, sehingga loin belum tumbah secara sempurna.

Leg merupakan komponen paling besar dari karkas. Leg yang didapatkan dari hasil penelitian berkisar $30,36 \%$ - 32,95\%, Berdasarkan AUS-MEAT (2005), persentase leg dalam karkas domba yaitu sekitar 32\%. Berdasarkan hasil persentase leg bersifat fluktuatif karena pada perlakuan suplementasi minyak sebesar $4 \%$ mengalami penurunan. Hal ini sejalan dengan hasil penelitian Rasmani (2010) yang menyatakan bahwa kecepatan pertumbuhan tidak memberikan dampak terhadap persentase leg.

\section{SIMPULAN}

Penambahan minyak biji bunga matahari sampai $6 \%$ dalam ransum komplit menghasilkan bobot potong, karakteristik dan potongan karkas komersial yang sesuai standar domba lokal muda.

\section{DAFTAR PUSTAKA}

[AUS-MEAT]. 2005. Sheep Meat. ISBN 0957879369 https://www.ausmeat.com.au/media/1275/9-sheepmeat.pdf. Diunduh 15 Juni 2019.

[BSN] Badan Standardisasi Nasional Indonesia. 2008. Mutu Karkas dan Daging Kambing/Domba. Standar Nasional Indonesia. 3925. Jakarta (ID): Badan Standardisasi Nasional Indonesia

[NRC] National Research Council. 2007. Nutrient Requirements of Small Ruminants: Sheep, Goats, Cervids, and New World Camelids. Washington DC (US): The National Academies Pr.

Ensminger M E. 2002. Sheep and Goat Science. Illinois (US): Interstate Publisher.

Francisco A, Dentinho MT, Alves SPP, Portugal V, Fernandes F, Sengo S, Jerónimo E, Oliveira MA, Costa P, Sequeira A, Bessa RJB, SantosSilva J. 2015. Growth performance, carcass and meat quality of lambs supplemented with increasing levels of a tanniferous bush (Cistus ladanifer L.) and vegetable oils. Meat Science. 100, p. 272282. https://doi.org/10.1016/j.meatsci.2014.10.014
Gatenby RM, Doloksaribu M, Bradford GE, Romjaii GE, Batubara L, Mirza I. 1995. Reproductive performance of sumatera and hair sheep crossbred ewes. SR-CRSP Annual Report 1994 - 1995, Sungai Putih, Sumatera Utara.

González L, Moreno T, Bispo E, Dugan MER, Franco D. 2014. Effect of supplementing different oils: Linseed, sunflower and soybean, on animal performance, carcass characteristics, meat quality and fatty acid profile of veal from "Rubia Gallega" calves. Meat Science. 96 (2): Part A. https://doi.org/10.1016/j.meatsci.2013.09.027

Hendri. 1986. Studi perbandingan distribusi perdagingan kambing kacang dan domba priangan pada dua tingkat umur. Karya Ilmiah. Fakultas Peternakan. Institut Pertanian Bogor.

Herman R. 1993. Perbandingan pertumbuhan komposisi tubuh dan karkas antara domba Priangan dan Ekor Gemuk. [disertasi]. Fakultas Pasca sarjana. Institut Pertanian Bogor. Bogor.

Lambuth TR, Kemp JD, Glimp HA. 1970. Effect of rate of gain a slaughter weight on lamb carcass composition. Journal of Animal Science. 30: 27-35.

Marinova P, Banskalieva, VS Alexandrov, Tzvetkova S, Stanchev V. 2001. Carcass Composition and meat qulity of kids fed sunflower oil supplemented diet. Small Rumminant Resources. 42 (3): 217-22. https://doi.org/10.1016/S0921-4488(01)00245-0.

Mir PS, McAllister TA, Zaman S, Morgan Jones, SD, He ML, Aalhus JL, Jeremiah LE, Goonewardene LA, Weselake RJ and Mir Z. 2003. Effect of dietary sunflower oil and vitamin $\mathrm{E}$ on beef cattle performance, carcass characteristics and meat quality. Canada Journal of Animal Science. 83: 53-66

Morgado E, Ezequiel JMB, Galzerano L, Sobrinho S. 2013. Performance and carcass characteristics of lambs fed with carbohydrate sources associated to sunflower oil. Bioscience Journal. 29 (3): 712-720

Purbowati E, Sutrisno CI, Baliarti E, Budhi SPS, Lestariana W. 2006. Karakteristik fisik otot longissimus dorsi dan biceps femoris domba lokal jantan yang dipelihara di pedesaan pada bobot potong yang berbeda. Jurnal Protein. 13(2):147-153

Rasmani. 2010. Komposisi fisik dan potongan komersial karkas domba lokal jantan pada tingkat kecepatan pertumbuhan yang berbeda dengan pemeliharaan secara intensif. Bogor (ID): IPB.

Rousset-Akrim S, Young OA, Berdague JL. 1997. Diet and growth effects in panel assessment of sheepmeat odour and flavour. Meat Science. 45:169-181.

Supriyati. 2012. Pertumbuhan kambing Peranakan Etawah prasapih yang diberi susu pengganti. Jurnal Ilmu Ternak dan Veteriner. 17(2): 142-151.

Rahayu, S, Astuti DA, Satoto KB, Priyanto R, Khotijah L, Suryati T, Baihaqi M 2011. Produksi domba balibu UP3 Jonggol melalui strategi perbaikan pakan berbasis Indigofera sp. dan limbah tauge. Laporan Penelitian Unggulan Fakultas. IPB, Dirjendikti Kementrian Pendidikan Nasional.

Radunz, AE, Wickersham LA, Loerch SC, Fluharty FL, Reynolds CK, and Zerby HN. 2009. Effects of dietary polyunsaturated fatty acid supplementation on fatty acid composition in muscle and subcutaneous adipose tissue of lambs. Journal of Animal Science. 87: 4082-4091.

Wiryawan KG, Astuti DA, Priyanto R, Suharti S. 2009. Optimalisasi pemanfaatan rumput dan legum pohon terhadap performa, produksi, dan kualitas daging domba jonggol. Laporan Penelitian 